\title{
PENGARUH KEMAMPUAN PRODUKSI, LUAS LAHAN DAN BIAYA PRODUKSI TERHADAP JUMLAH PRODUKSI SERTA PENDAPATAN PETANI PISANG
}

\author{
I Putu Agus Ari Wiguna ${ }^{1}$ \\ Ida Bagus Putu Purbadharmaja² \\ ${ }^{1,2}$ Fakultas Ekonomi dan Bisnis Universitas Udayana (Unud), Bali, Indonesia \\ E-mail: agusariwiguna28@gmail.com
}

\begin{abstract}
Effect of Production Capability, Land Area and Production Costs on Production Amounts and Banana Farmer Income. This research was conducted in Selemadeg Barat District, Tabanan Regency with respondents from banana farmers covering the area of each village in Selemadeg Barat District, Tabanan Regency. The sampling technique used is Simple Random Sampling. Sample in this study amounted to 92 respondents. This study uses path path analysis techniques to analyze the direct influence between variables one with other variables and the sobel test analyzes indirect effects through intervening variables. Based on the results of the study concluded that the production capacity, land area, and production costs have a positive and significant effect on the amount of banana production in the Selemadeg Barat District. Production capability has a positive and insignificant effect on the income of banana farmers in Selemadeg Barat District. Production costs have a negative and insignificant effect on the income of banana farmers in Selemadeg Barat District. Production capability, land area, and production costs have an indirect influence on the income of banana farmers through the amount of production in the District of West Selemadeg.
\end{abstract}

Keywords: production capability, land area, production costs, total production, income

\begin{abstract}
Abstrak: Pengaruh Kemampuan Produksi, Luas Lahan dan Biaya Produksi Terhadap Jumlah Produksi Serta Pendapatan Petani Pisang. Penelitian ini dilakukan di Kecamatan Selemadeg Barat, Kabupaten Tabanan dengan responden petani pisang meliputi wilayah masingmasing desa yang ada di Kecamatan Selemadeg Barat, Kabupaten Tabanan. Teknik sampling yang digunakan adalah Simple Random Sampling. Sample pada penelitian ini berjumlah 92 responden. Penelitian ini menggunakan teknik analisis jalur path untuk menganalisis pengaruh langsung antara variabel satu dengan variabel lainnya dan uji sobel menganalisis pengaruh tidak langsung melalui variabel intervening. Berdasarkan hasil penelitian diperoleh kesimpulan bahwa kemampuan produksi, luas lahan, dan biaya produksi berpengaruh positif dan signifikan terhadap jumlah produksi pisang di Kecamatan Selemadeg Barat. Kemampuan produksi mempunyai pengaruh positif dan tidak signifikan terhadap pendapatan petani pisang di Kecamatan Selemadeg Barat. Biaya produksi mempunyai pengaruh negatif dan tidak signifikan terhadap pendapatan petani pisang di Kecamatan Selemadeg Barat. Kemampuan produksi, luas lahan, dan biaya produksi memiliki pengaruh tidak langsung terhadap pendapatan petani pisang melalui jumlah produksi di Kecamatan Selemadeg Barat.
\end{abstract}

Kata kunci: kemampuan produksi, luas lahan, biaya produksi, jumlah produksi, pendapatan 


\section{PENDAHULUAN}

Indonesia dikenal sebagai negara agraris yang berarti negara yang mengandalkan sektor pertanian disamping itu juga mengandalkan sektor perkebunan. Peran sektor pertanian dan perkebunan merupakan dasar bagi kelangsungan pembangunan ekonomi yang berkelanjutan diharapkan mampu memberikan pemecahan permasalahan bagi bangsa Indonesia, dikarenakan pada sektor pertanian dan perkebunan merupakan sektor yang mempunyai fungsi fundamental bagi pembangunan suatu bangsa (Dillon, 2004). Sebagian besar wilayah Indonesia di sektor pertanian dan perkebunan menjadi prioritas utama dalam penunjang perekonomiannya. Selain itu, sektor pertanian dan perkebunan di kenal secara umum sebagai salah satu sektor yang relatif cukup lambat dalam mengadopsi perkembangan teknologi, serta sektor yang paling rawan terkena dampak negatif dari perubahan iklim. Negara berkembang yang sebagian besar penduduknya bertumpu pada aktivitas pertanian, perkembangan teknologi dalam proses produksi pertanian dilaporkan membawa dampak positif dan dampak positif yang dimaksud adalah peningkatan dalam produksi pertanian (Sukartini, 2013). Ketika suatu negara berusaha untuk mempercepat pertumbuhan ekonominya sedangkan disisi lain yang akan halnya memprioritaskan pengembanganindustridaripadapembangunan pertanian yang pertama akan lebih nyata, cepat dan terlihat dari pada pengembangan industri, di Indonesia memiliki investasi yang sangat kurang di dalam bidang pertanian yang akan menyebabkan pertanian yang tidak efisien subsidi dan beberapa ekonomi masayarakat yang berpendapatan menengah tidak memiliki transformasi pertanian yang memadai (Jeon, 2013).

Negara berkembang seperti Indonesia ini memiliki wilayah sebagian besar pada sektor pertanian dan perkebunan menjadi prioritas utama dalam penunjang perekonomian. Untuk itu mengutamakan kepentingan kesejahteraan masyarakat melalui sektor pertanian dan perkebunan dengan cara mendapatkan pekerjaan khususnya sebagai petani. Dalam hal ini menjadikan sektor pertanian dan perkebunan yang lebih maju diharapkan masyarakat yang sebagai petani dapat meningkatkan produktivitasnya, dimana hal tersebut menjadikan faktor yang penting dalam menunjang keberhasilan suatu usaha pada sektor pertanian dan perkebunan (Adi Wiguna, 2018). Hal ini diperkuat dalam penelitian (Mannan \& Shahrina, 2014) yang mengatakan negara-negara di Asia pada tahun 2007 memperoleh pendapatannya melalui sektor pertanian dan perkebunan, sehingga pertanian dan perkebunan memang benarbenar harus dikerjakan lebih baik lagi.

Sektor pertanian dan perkebunan membuahkan hasil yang dapat di manfaatkan sebagai bahan baku industri dan sumber bahan pangan yang dapat menjadikan sektor pertanian dan perkebunan tersebut semakin penting, maka dari itu diharapkan pada sektor pertanian dan perkebunan dapat menjadi penggerak sektor-sektor ekonomi di dalam pembangunan ekonomi pedesaan, yang dimana adanya sektor pertanian dan perkebunan ini mencakup komponen sosial, ekonomi, lingkungan, dan kelembagaan (Jelocnik, 2011). Hal ini juga disampaikan dalam penelitaian Lincoln dan Nicole (2016) bahwa pertanian dan perkebunan memberikan berbagai macam manfaat dan dampak kepada masyarakat, termasuk lingkungan, ekonomi, sosial dan budaya. Sektor pertanian dan perkebunan umumnya merupakan sektor yang dapat ditangkap untuk investasi (Winters, 1998).

Salah satu sub sektor di sektor pertanian adalah sub sektor perkebunan (Berihun dan Bihon, 2014). Dalam mengembangkan perekonomian khususnya sektor perkebunan adalah salah satu kegiatannya untuk meningkatkan kesejahteraan masyarakat dalam arti tingkat hidup yang lebih maju maupun taraf hidup yang lebih bermutu, dimana semakin besar kegiatan ekonomi khususnya sektor perkebunan maka semakin luas lapangan kerja produktif bagi masyarakat. Sub sektor perkebunan ini semakin penting dalam meningkatkan pertumbuhan ekonomi nasional, mengingat juga semakin terbatasnya 
peranan minyak bumi yang selama ini merupakan sumber utama devisa negara (Francis, 2011).

Untuk meningkatkan pertumbuhan ekonomi di pedesaan yaitu melalui sektor pertanian dan perkebunan untuk mengatasi kemiskinan khususnya di pedesaan yang dimana sebagian besar masyarakat di pedesaan hidup miskin (Suryahadi et all, 2012). Dampak distribusi dari ekonomi makro pada saat ini cenderung sulit dirasakan oleh masyarakat miskin di Indonesia yaitu banyak orang miskin di Indonesia bekerja di bidang pertanian atau informal dan mayoritas masyarakat Indonesia mengandalkan pada sektor pertanian dan perkebunan, terutama bagi masyarakat yang tinggal di wilayah pedesaan (Yusuf dan Sumner, 2015).

Salah satunya adalah komoditi pertanian yang dikembangkan petani yaitu hortikultura. Petani berupaya meningkatkan pendapatan dengan mengusahakan komoditi ini sehingga dapat memenuhi kebutuhan pokoknya (Alitawan, 2013). Petani secara umumnya memiliki tujuan untuk memaksimumkan keuntungan yang akan diperoleh dari usahataninya (Mariyah, 2018). Keberhasilan pembangunan pertanian ditentukan oleh keberhasilan tumbuhnya lingkungan komoditas pertanian tanaman pangan, holtikultura, perkebunan, perikanan, dan peternakan yang masih kental dalam kehidupan masyarakat di setiap provinsi yang tersebar di Indonesia (Ardika, 2017). Kesenjangan antardaerah akan semakin besar perbedaannya akibat perbedaan geografis seperti halnya ketimpangan antara daerah perkotaan dengan pedesaan (Breau dan Saillant, 2016).

Hortikultura merupakan pertanian yang diperuntukkan bagi budidaya tanaman kebun. Bidang kerja hortikultura meliputi pembenihan, pembibitan, kultur jaringan dan lainnya. Hortikultura merupakan salah satu metode budidaya pertanian modern. Salah satu jenis tanaman hortikultura yaitu hortikultura sayuran meliputi kangkung, bayam dan lainnya, tanaman hortikultura dibagi dalam jenis tanaman buah dan bukan tanaman buah.
Tanaman buah ini biasanya disebut sebagai tanaman musiman. Jadi tanaman buah akan berbuah pada musim buah tertentu. Ada jenis tanaman buah yang hanya berbuah satu kali dalam masa tanam dan juga ada yang berbuah berkali-kali selama ditanam. Adapun salah satu jenis tanaman buah yang hanya berbuah sekali saja adalah buah pisang.

Provinsi Bali membutuhkan hasil-hasil hortikultura salah satunya adalah pisang. Selain untuk di konsumsi, buah pisang ini biasanya di haturkan dalam proses persembahyangan atau upacara adat khususnya umat Hindu yang ada di Bali, dengan demikian permintaan masyarakat akan buah pisang tetap tinggi selain digunakan untuk persembahyangan juga dapat dijadikan olahan pisang lainnya. Tanaman pisang bagi masyarakat Bali merupakan komoditas yang sudah memasyarakat, memiliki nilai ekonomis dan sosial yang sangat penting, tidak hanya buahnya saja tetapi juga daun, anakan serta batangnya sangat diperlukan dalam menunjang kehidupan sehari-hari, oleh karena tingkat kemanfaatannya yang cukup tinggi bagi masyarakat Hindu di Bali, tidaklah berlebihan bila tanaman pisang di Bali dianggap sebagai komoditas strategis (Antara, 2013).

$$
\text { Dalam hal ini kemampuan }
$$
memproduksi pisang di Bali ternyata masih rendah melihat permintaan pisang sangat tinggi pada hari raya keagamaan seperti Galungan maupun Kuningan, hal ini menyebabkan kekurangan ketersediaan pisang akan tingginya permintaan di pasar, sehingga untuk memenuhi kebutuhan buah pisang di hari raya maka masuklah buah pisang dari daerah luar Bali, seperti dari daerah Jawa Timur, Nusa Tenggara Barat dan lainnya. Penelitian ini didasarkan pada fenomena fakta yang terjadi pada saat ini. Jumlah faktor produksi yang digunakan menentukan jumlah produksi yang ingin dicapai (Prasetyo,2017). Produksi merupakan suatu proses kegiatan pengolahan bahan baku menjadi barang yang bernilai guna produksi merupakan proses transformasi (perubahan) dari input menjadi output (Budiartha,2013).

Salah satu Kabupaten yang ada di Provinsi Bali yang menghasilkan buah 
Tabel 1.

Luas Lahan Pertanian dan Perkebunan di Kabupaten TabananTahun 2013-2017

\begin{tabular}{lrrrrr}
\hline \multicolumn{1}{c}{ Jenis Lahan } & $\begin{array}{c}\mathbf{2 0 1 3} \\
\text { (ha) }\end{array}$ & $\begin{array}{c}\text { 2014 } \\
\text { (ha) }\end{array}$ & \multicolumn{1}{c}{$\begin{array}{c}\text { 2015 } \\
\text { (ha) }\end{array}$} & \multicolumn{1}{c}{$\begin{array}{c}\text { 2016 } \\
\text { (ha) }\end{array}$} & \multicolumn{1}{c}{\begin{tabular}{c}
\multicolumn{1}{c|}{ (ha) } \\
(ha)
\end{tabular}} \\
\hline Sawah Irigasi & 22184 & 21962 & 21714 & 21452 & 21089 \\
Perkebunan & 22606 & 22606 & 22667 & 22666 & 22631 \\
Tegal/kebun & 15809 & 15980 & 16024 & 16162 & 16627 \\
Ditanami pohon/hutan rakyat & 1784 & 1784 & 1784 & 1783 & 1783 \\
\hline Sumber:Dinas Pertanian Kabupaten Tabanan, 2018 & & & & &
\end{tabular}

Tabel 2.

Jumlah Produksi Tanaman Perkebunan Pisang Perkecamatandi Kabupaten Tabanan dalam kuintal Tahun 2014-2017

\begin{tabular}{llrrrr}
\hline No & Kecamatan & \multicolumn{4}{c}{ Produksi (dalam kuintal) } \\
& & $\mathbf{2 0 1 4}$ & $\mathbf{2 0 1 5}$ & $\mathbf{2 0 1 6}$ & \multicolumn{1}{c}{$\mathbf{2 0 1 7}$} \\
\hline $\mathbf{1}$ & Selemadeg Barat & $\mathbf{2 3 . 4 5 7}$ & $\mathbf{8 9 . 0 7 0}$ & $\mathbf{3 2 . 6 4 2}$ & $\mathbf{9 0 0 . 2 5 2}$ \\
2 & Selemadeg & 2.851 & 11.521 & 1.955 & 3.406 \\
3 & Selemadeg Timur & 59 & 56 & 66 & 50 \\
4 & Kerambitan & 924 & 47 & 1.295 & 1.290 \\
5 & Tabanan & 1.104 & 735 & 496 & 503 \\
6 & Kediri & 114 & 364 & 20 & 11 \\
7 & Marga & 333 & 270 & 525 & 13 \\
8 & Baturiti & 7.685 & 17.217 & 14.195 & 5.104 \\
9 & Penebel & 244 & 12.106 & 1.560 & 9.914 \\
10 & Pupuan & 13.934 & 11.608 & 25.550 & 0 \\
& Total & $\mathbf{5 0 . 7 0 5}$ & $\mathbf{1 4 2 . 9 9 4}$ & $\mathbf{7 8 . 3 0 4}$ & $\mathbf{9 2 0 . 5 4 3}$ \\
\hline
\end{tabular}

Sumber: Dinas Pertanian Kabupaten Tabanan, 2018

pisang yaitu Kabupaten Tabanan. Kabupaten Tabanan merupakan salah satu lahan pertanian dan perkebunan yang cukup luas. Penghasilan masyarakat yang ada di Kabupaten Tabanan dari dataran tinggi atau daerah pegunungan bersumber dari hasil perkebunan yang mereka miliki, seperti hasil kebun pisang, kakao, kopi, cengkeh dan lainnya. Berikut merupakan luas lahan pertanian dan perkebunan di Kabupaten Tabanan.

Berdasarkan Tabel 1 Menunjukkan bahwa perkembangan luas lahan perkebunan di Kabupaten Tabanan pada tahun 2013 terdapat 22.606 hektar, pada tahun 2014 tidak terjadi perubahan penggunaan luas lahan, pada tahun 2015 mengalami kenaikkan menjadi 22.667 hektar, di tahun 2016 mengalami penurunan menjadi 22.666 hektar, dan pada tahun 2017 mengalami penurunan menjadi 22.631 hektar. Jadi pada tahun 2013 sampai tahun 2017 mengalami fluktuasi. Luas lahan yang digunakan dalam teknik budidaya pisang ini belum mengarah ke pertanian agribisnis, jadi dilakukan sebagi usaha tani sampingan, ditanam di sela-sela tanaman perkebunan seperti kopi, cengkeh, kakao atau ditanam di pekarangan. Dalam hal ini luas lahan yang digunakan adalah hal yang sangat penting untuk memproduksi pisang agar memaksimalkan hasil produksi. Dalam hal ini Gouse (2006), Shan \& Anran (2015) mendapatkan hasil bahwa faktor luas lahan berpengaruh signifikan terhadap jumlah produksi dan pendapatan petani.

Beraneka ragam hasil perkebunan yang ada di Kabupaten Tabanan seperti pisang yang merupakan salah satu komoditas hortikultura yang layak untuk dikembangkan, walaupun nilainya tidak terlalu tinggi bagi petani pisang, tetapi dapat dijadikan sebagai 
Tabel 3.

Jumlah Petani Pisang Menurut Desa di Kecamatan SelemadegBarat Kabupaten Tabanan Tahun 2018

\begin{tabular}{clc}
\hline No & \multicolumn{1}{c}{ Desa } & Jumlah Petani Pisang (orang) \\
\hline 1 & Lumbung Kauh & 370 \\
2 & Mundeh & 380 \\
3 & Mundeh Kauh & 300 \\
4 & Mundeh Kangin & 170 \\
& $\quad$ Jumlah & $\mathbf{1 . 2 2 0}$ \\
\hline
\end{tabular}

Sumber: UPTD Kecamatan Selemadeg Barat, 2018

sumber pendapatan petani. Berikut tabel produksi pisang di Kabupaten Tabanan.

Berdasarkan Tabel 2 menunjukkan bahwa perkembangan produksi pisang di Kecamatan Selemadeg Barat yang memproduksi pisang pada tahun 2014-2017 dalam satuan kuintal, yakni pada tahun 2014 produksi pisang sebesar 23.457 kuintal, pada tahun 2015 mengalami peningkatan sebesar 65.613 kuintal dari tahun sebelumnnya menjadi 89.070 kuintal, namun pada tahun 2016 Produksi Pisang mengalami penurunan sebesar 56.428 kuintal dari tahun sebelumnya menjadi 32.642 kuintal. Produksi Pisang pada tahun 2017 mengalami kenaikan yang cukup tinggi yaitu sebesar 867.610 kuintal dari tahun sebelumnya menjadi 900.252 kuintal. Produksi pisang ini mengalami kenaikkan yang cukup tinggi pada tahun terakhir yaitu tahun 2017.

Wilayah yang menghasilkan pisang di Kecamatan Selemadeg Barat yaitu Desa Lumbung Kauh, Desa Mundeh, Desa Mundeh Kauh, dan Desa Mundeh Kanginmerupakan desa yang menghasilkan buah pisang terbanyak. Berikut jumlah petani pisang di Kecamatan Selemadeg Barat dapat dilihat pada tabel 3.

Tabel 3 memberikan informasi bahwa jumlah petani pisang di Kecamatan Selemadeg Barat pada tahun 2018 yaitu sebanyak 1.220 KK, yang terdiri dari Desa Lumbung Kauhsebanyak 370 KK, Desa Mundeh sebanyak 380 KK, Desa Mundeh Kauh sebanyak 300 KK, dan Desa Mundeh Kangin sebanyak $170 \mathrm{KK}$.

Selain luas lahan yang menjadi permasalahan yang dihadapi oleh petani pisang, salah satunya adalah kendala pada biaya produksi. Biaya produksi yang dipakai untuk membeli bibit dan pupuk sangat kecil sehingga hasil produksinya tidak maksimal, (Mushi, 2015) dan Nian (2017) juga mengatakan bahwa ketersediaan biaya produksi yang tepat sesuai dengan kebutuhan dalam produksi usahatani akan mempengaruhi produksi pertanian tersebut. Merujuk pada permasalahan yang ditunjukkan pada tabel 2 cenderung menurunnya produksi pisang pada periode 2016 dibandingkan dengan tahun 2015, ini menandakan kemungkinan besar penyebab nilai produksi pisang berupa biaya produksi di Kecamatan Selemadeg Barat Kabupaten Tabanan cenderung mengalami penurunan dan kenaikan yang silih berganti pada setiap tahun adalah kolaborasi antara penggunaan input, biaya produksi dan yang tidak dikelola secara efisien mengakibatkan jumlah produksi yang dihasilkan tidak optimal.

Terkendalanya teknik produksi atau pengetahuan petani pisang yaitu dalam berusahatani atau kemampuan untuk berproduksi yang mengakibatkan penurunan jumlah produksi. Mulai dari teknik penanaman, perawatan, hingga pemanenan yang baik sehingga menghasilkan jumlah produksi yang maksimal. Didalam kemampuan produksi terhadap produksi diantaranya melalui tenaga kerja, Setiawati (2013) menyatakan bahwa tenaga kerja berpengaruh positif terhadap hasil produksi, yang dilakukan dalam kemampuan produksi tersebut dapat berupa dari pemahaman petani dalam melakukan proses produksi, jika petani tersebut paham akan proses bertani sehingga menghasilkan dan memaksimalkan produksi yang lebih 
baik. Petani pisang juga mengatakan sulit dalam hal memasarkan pisang, apabila tidak segera menjual pisang tersebut terhadap pengepul maka pisang dapat busuk, sehingga dapat menyebabkan kualitas pisang ditandai dengan munculnya jamur yang nantinya akan mempengaruhi pembentukan harga pisang tersebut, sehingga produksi pisang terancam tidak maksimal karena disisi lain petani mengeluarkan biaya dalam produksi tersebut. Pendapatan merupakan salah satu indikator untuk mengukur kesejahteraan seseorang atau masyarakat, sehingga pendapatan dapat mencerminkan kemajuan ekonomi suatu masyarakat. Indikator yang dimaksud hanya bersangkutan dengan pendapatan dan pengeluaran, akan tetapi yang lebih penting adalah mengetahui besarnya perbandingan antara penerimaan dengan pengeluaran (Suryaniti, 2018). Produksi secara luas dapat diartikan sebagai pengolahan bahan baku menjadi barang setengah jadi atau barang jadi. Produksi dalam arti ekonomi mempunyai pengertian semua kegiatan untuk menambah atau meningkatkan nilai kegunaan (utility) suatu barang dan jasa. Di dalam ilmu ekonomi dikenal dengan adanya fungsi produksi yang menunjukkan adanya hubungan antara hasil produksi fisik (output) dengan faktor produski (input).

Tenaga kerja merupakan faktor produksi yang berperan penting dalam proses produksi pertanian. Penggunaan tenaga kerja akan lebih intensif apabila tenaga kerja tersebut dapat memberikan manfaat yang optimal dalam proses produksi dan mampu menggarap lahan seluas lahan yang dimiliki. Tenaga kerja akan diberi upah sebagai tanda balas jasa. Tenaga kerja yang memanfaatkan keluarga sendiri dalam proses produksi pada umumnya tidak terlalu diperhitungkan dan sulit diukur dalam penggunaannya atau bisa disebut sebagai tenaga kerja yang tidak dinilai dengan uang. Menurut UU No 13 Tahun 2003 Tentang Ketenagakerjaan menyatakan bahwa tenaga kerja adalah setiap orang yang mampu melakukan pekerjaan guna menghasilkan barang dan/atau jasa baik untuk memenuhi kebutuhan sendiri maupun untuk kebutuhan masyarakat.

Indikator pemahaman menunjukkan bahwa pemahaman mengandung makna lebih luas atau lebih dalam dari pengetahuan. Dengan pengetahuan, seseorang belum tentu memahami sesuatu yang dimaksud secara mendalam, hanya sekedar mengetahui tanpa bisa menangkap makna dan arti dari sesuatu yang dipelajari. Sedangkan dengan pemahaman, seseorang tidak hanya bisa menghapal sesuatu yang dipelajari, tetapi juga mempunyai kemampuan untuk menangkap makna dari sesuatu yang dipelajari juga mampu memahami konsep dari pelajaran tersebut. Dalam pemahaman produksi, petani diharapkan dapat memahami cara membudidayakan pertanian pisang dari beberapa segi seperti pengolahan tanah, pengolahan tanah yang dimaksud bukan kegiatan yang mutlak harus dilakukan, khususnya pada lahan yang masih gembur dan tidak terdapat gulma.

Sukirno (2002 :4) mengatakan bahwa tanah sebagai faktor produksi adalah tanah yang mencakup bagian permukaan bumi yang dapat dijadikan untuk bercocok tanam juga tempat tinggal, dan kekayaan alam yang terdapat didalamnya. Pengusaan tanah bagi masyarakat merupakan unsur yang sangat penting dalam meningkatkan kesejahteraan di bidang pertanian. Biaya produksi dapat didefinisikan sebagai semua pengeluaran yang dilakukan oleh perusahaan atau produsen untuk memperoleh faktor-faktor produksi dan bahan-bahan mentah yang akan digunakan untuk menciptakan barang-barang yang diproduksikan produsen tersebut (Sadono, 2016).

Biaya produksi yang dikeluarkan setiap perusahaan dapat dibedakan menjadi dua jenis yaitu biaya eksplisit dan biaya tersembunyi (imputed cost). Biaya eksplisit adalah pengeluaran-pengeluaran produsen yang berupa pembayaran dengan uang untuk mendapatkan faktor-faktor produksi dan bahan mentah yang dibutuhkan. Sedangkan biaya tersembunyi adalah biaya yang tidak terlihat secara langsung, seperti biaya penyusutan barang modal (Sadono, 2016). Untuk 
menghasilkan barang atau jasa diperlukan faktor-faktor produksi seperti bahan baku, tenaga kerja, modal, dan keahlian produsen. Semua faktor-faktor produksi yang dipakai merupakan pengorbanan dari proses produksi dan juga berfungsi sebagai ukuran untuk menentukan harga pokok barang.

Di dalam sektor pertanian adanya hubungan yang mempengaruhi kemampuan produksi dengan produksi diantaranya melalui tenaga kerja, pemahaman produksi oleh petani, dan luas lahan yang dimiliki oleh petani. Dalam melakukan produksi hal yang berperan penting adalah ketenagakerjaan yang akan melaksanakan proses dari produksi tersebut dan menghasilkan berupa barang maupun jasa. Penelitian yang dilakukan oleh Salazar (2006), Saputra (2015), Abedullah et al. (2007), Adriyansyah (2017), dan Adojutelegan et al. (2015) mendapatkan hasil bahwa tenaga kerja berpengaruh positif dan signifikan terhadap produksi. Begitu juga dengan adanya pemahaman produksi oleh petani yang dimana dimaksudkan dengan tingkat pemahaman seorang petani yang paham dengan pertanian pisang baik dari proses awal sampai menghasilkan sebuah produksi dalam bertani akan memberikan dorongan untuk hasil produksi yang lebih baik dan terpentingnya luas lahan yang menyangkut dari adanya produksi yang dapat menghasilkan produksi menurut luas lahan yang dimiliki oleh petani pisang tersebut. Lahan merupakan hal yang paling utama dalam usahatani, dimana semakin luas lahan maka semakin besar jumlah produksi yang mampu dihasilkan oleh petani (Ambarita, 2017).

Pada penelitian yang dilakukan oleh Gouse (2006), Shan \& Anran (2015) mendapatkan hasil bahwa faktor luas lahan berpengaruh signifikan terhadap produksi dan Aldillah (2015) melakukan penelitian yang menemukan luas lahan memiliki pengaruh nyata terhadap produksi. Artinya apabila semakin luas lahan pertanian maka jumlah produksi petani akan semakin meningkat. Hal ini konsisten dengan penelitian yang dilakukan oleh Adojutelegan et al.(2015) dan Oluyole dan Sanusi (2009) yang menemukan hasil bahwa semakin luas lahan yang digunakan dalam proses produksi, maka akan dapat meningkatkan hasil produksi.

Ketersediaan biaya produksi seperti jumlah pupuk dan bibit yang digunakan, sangat erat kaitannya dengan produksi. Ketersediaannya biaya produksi dalam pertanian yang menjadikan dasar dari sebuah hasil produksi, dimana ketersediaan biaya produksi tersebut meliputi jumlah bibit yang digunakan dan seberapa banyak pupuk yang digunakan akan berpengaruh terhadap hasil produksi yang dilakukan dalam pertanian pisang, dan jika sebaliknya jumlah bibit dan pupuk yang digunakan sedikit akan berpengaruh juga terhadap produksi yang dilakukan. Ketersediaan jumlah modal maupun biaya produksi yang tepat sesuai dengan kebutuhan dalam produksi usaha tani akan mempengaruhi produksi pertanian tersebut (Nian, 2017)

Berbagai hal yang dilakukan dalam melakukan produksi yang dapat menentukan besaran hasil pendapatan. Yang dilakukan dalam kemampuan produksi tersebut dapat berupa dari pemahaman petani dalam melakukan proses produksi, jika petani tersebut paham akan proses bertani sehingga menghasilkan produksi yang lebih baik hasilnya akan mempengaruhi tingkat penjualan dan memberikan pendapatan yang meningkat. Disamping itu luas lahan juga berpengaruh dalam kemampuan produksi, semakin luas dan efektif lahan yang dimilki oleh petani tersebut akan menghasilkan banyak produksi yang akan berpengaruh pada pendapatan petani. Hubungan luas lahan pertanian dengan pendapatan petani menurut Mubyarto (1995:44) luas lahan adalah keseluruhan wilayah yang menjadi tempat penanaman atau mengerjakan proses penanaman, luas lahan menjamin jumlah atau hasil yang akan diperoleh petani.

Tersedianya biaya produksi atau bahan baku, erat kaitannya dengan biaya produksi yang dikeluarkan oleh petani, sehingga pemberian bahan baku berupa pupuk berpengaruh terhadap pendapatan petani. 
Dalam setiap produksi yang dilakukan oleh petani bila pupuk di kurangi akan menambah biaya produksi sehingga pendapatan petani menurun. Sebaliknya, bila pupuk di berikan maka akan mengurangi biaya produksi petani sehingga pendapatan petani meningkat.

Menurut Limi (2013), menunjukkan bahwa terdapat hubungan yang positif antara jumlah produksi terhadap pendapatan. Artinya, semakin tinggi jumlah produksi yang dihasilkan maka akan semakin tinggi pendapatan yang diperoleh. Jumlah produksi akan sangat dipengaruhi oleh luas tanah yang ditanami, biaya produksi yang digunakan, pemeliharaan dan faktor-faktor lainnya, hal ini juga sesuai dengan penelitian Godby (2015), yang menyatakan bahwa tingkat produksi akan berbanding lurus dengan tingkat pendapatan yang di peroleh seseorang.

\section{METODE PENELITIAN}

Lokasi Penelitian ini dilakukan di Kecamatan Selemadeg Barat, Kabupaten Tabanan. Dipilihnya lokasi ini karena Kecamatan Selemadeg Barat merupakan daerah penghasil pisang terbesar di Kabupaten Tabanan. Kecamatan Selemadeg Barat merupakan daerah pegunungan yang berbukitbukit di bagian utara dan melandai kearah selatan dengan ketinggian $0 \mathrm{~s} / \mathrm{d} 700 \mathrm{~m}$ dari permukaan laut, curah hujan relatiif banyak di wilayah utara (wilayah pegunungan dan berbukit-bukit) sehingga penduduk setempat sebagian besar bermata pencaharian sebagai petani kebun.

Populasi yang digunakan peneliti dalam penelitian ini Petani Pisang di Kecamatan Selemadeg Barat, Kabupaten Tabanan yang berjumlah 1.220 petani pisang, dengan pertimbangan Desa Lumbung Kauh, Desa Mundeh, Desa Mundeh Kauh, dan Desa Mundeh Kangin, Kecamatan Selemadeg Barat merupakan daerah penghasil pisang terbesar di Kabupaten Tabanan. Dalam penelitian ini tidak semua anggota populasi dijadikan responden, tetapi hanya sebagian saja yaitu dengan mengambil sampel. Hal ini, dikarenakan oleh populasi relatif besar dan adanya kendala sumber daya seperti dana, waktu, dan sumber daya lainnya yang dimiliki. Jumlah sampel dalam penelitian ini ditentukan berdasarkan jumlah petani pisang yang terdapat di Kecamatan Selemadeg Barat, Kabupaten Tabanan, sampel mewakili populasi yang jumlahnya lebih kecil dari pada populasi serta mampu menggambarkan keadaan yang sebenarnya dari populasi. Dalam penelitian ini sampel diambil menggunakan teknik Probability sampling.

Penelitian ini mengambil Lokasi di 4 Desa Kecamatan Selemadeg Barat, dimana jumlah petani pisang di Kecamatan Selemadeg Barat 1.220 petani pisang (KK).

Jumlah anggota sampel yang diambil atau ukuran sampelnya yang minimal akan ditentukan menggunakan pendekatan Slovin (Amira, 2011) sebagai berikut :

$$
\mathrm{n}=\frac{\mathrm{N}}{1+\mathrm{Ne}^{2}}
$$

$\mathrm{n}=$ ukuran sampel, $\mathrm{N}=$ ukuran anggota dalam populasi, dan e = tingkat kekeliruan,

Petani pisang di Kecamatan Selemadeg Barat sebanyak orang $(\mathrm{N}=1.220)$, dengan menggunakan tingkat kekeliruan sebesar $0,1(\mathrm{e}=0,1)$, maka jumlah sampel/ ukurann sampel minimalnya (n) adalah :

$$
\begin{aligned}
& \mathrm{n}=\frac{\mathrm{N}}{1+\mathrm{Ne}^{2}} \\
& \mathrm{n}=\frac{1.220}{1+(1.220 \times 0,12)} \\
& \mathrm{n}=\frac{1.220}{1+12.2} 92 \text { (dibulatkan) }
\end{aligned}
$$

Jadi, jumlah sampel yang diperoleh adalah sebesar 92 petani pisang. Dalam hal pengambilan sampel, pada penelitian ini menggunakan teknik pengambilan sampel Simple Random Sampling karena pengambilan sampel anggota populasi dilakukan secara acak tanpa memperhatikan strata yang ada dalam populasi itu.

$\mathrm{n}_{i}=\frac{\mathrm{N}_{i}}{\mathrm{~N}} \times n$

Keterangan :

$\mathrm{n}_{i}=$ ukuran sampel ke-i

$\mathrm{N}_{i}=$ ukuran sub populasi ke-i

$\mathrm{N}=$ ukuran populasi

$\mathrm{n}=$ ukuran sampel

Dengan menggunakan rumus (3.4), 
Tabel 4.

Jumlah Sampel Petani Pisang (orang) di Kecamatan Selemadeg Barat Kabupaten Tabanan

Tahun 2018

\begin{tabular}{|c|c|c|c|}
\hline No & Nama Desa & Jumlah Petani Pisang & Jumlah Sampel \\
\hline 1 & Lumbung Kauh & 370 & $370 / 1.220 \times 92=28$ \\
\hline 2 & Mundeh & 380 & $380 / 1.220 \times 92=29$ \\
\hline 3 & Mundeh Kauh & 300 & $300 / 1.220 \times 92=22$ \\
\hline 4 & Mundeh Kangin & 170 & $170 / 1.220 \times 92=13$ \\
\hline & Total & 1.220 & 92 Orang Petani Pisang \\
\hline
\end{tabular}

Sumber:Data diolah, 2018

Tabel 5.

Hasil Uji KMO

\begin{tabular}{cccc}
\hline No & Faktor & KMO & Sig Chi-square \\
\hline 1 & Kemampuan produksi & 0,744 & 0,000 \\
\hline Sumber:Data diolah, 2019
\end{tabular}

Tabel 5.

Hasil Uji KMO

\begin{tabular}{ccc}
\hline Variabel & Indikator & Nilai MSA \\
\hline \multirow{3}{*}{ Kemampuan Produksi (X1) } & $\mathrm{X} 1.1$ & 0,722 \\
& $\mathrm{X} 1.2$ & 0,749 \\
& $\mathrm{X} 1.3$ & 0,763 \\
\hline
\end{tabular}

Sumber:Data diolah, 2019

maka didapatkan sampel untuk di masingmasing desa di Kecamatan Selemadeg Barat, dapat dilihat pada tabel 4 sebagai berikut.

Teknik analisis data yang digunakan untuk memecahkan permasalahan dalam penelitian ini adalahteknik analisis kuantitatif dengan bantuan program SPSS. Metode analisis yang digunakan pada penelitian ini adalah analisis jalur (path analysis).

Maka dapat dibuat persamaan structural sebagai berikut:

$\mathrm{Y}_{1}=\mathrm{b}_{1} \mathrm{X}_{1}+\mathrm{b}_{2} \mathrm{X}_{2}+\mathrm{b}_{3} \mathrm{X}_{3} \mathrm{e}_{1}$

Penelitian pengaruh kemampuan produksi, luas lahan dan biaya produksi terhadap jumlah produksi serta pendapatan petani pisang di Kecamatan Selemadeg Barat, Kabupaten Tabanan.

$\mathrm{Y}_{2}=\mathrm{b}_{4} \mathrm{X}_{1}+\mathrm{b}_{5} \mathrm{X}_{2}+\mathrm{b}_{6} \mathrm{X}_{3}+\mathrm{b}_{7} \mathrm{Y}_{1}+\mathrm{e}_{2}$

Keterangan:

$\mathrm{e}_{1}, \mathrm{e}_{2}=$ error term

\section{HASIL DAN PEMBAHASAN}

Kaiser Meyer Olkin digunakan untuk mengetahui validitas konstruk dari analisis faktor. Analisis faktor dianggap layak jika besaran KMO memiliki nilai minimal 0,5. Hasil uji KMO dapat dilihat pada Tabel 5 berikut:

Hasil uji yang ditunjukkan dalam Tabel 5 menunjukkan bahwa nilai Kaiser Meyer Olkin (KMO) variabel kemampuan produksi lebih besar dari 0,5 dan nilai signifikansinya lebih kecil dari 5 persen $(0,05)$, maka ini berarti variabel kemampuan produksi memiliki kecukupan sampel yang melakukan analisis faktor.

Kelayakan model uji faktor untuk $\mathrm{Y}_{2}=$ Pendapatan Petani

$\mathrm{Y}_{1}=$ Jumlah Produksi

$\mathrm{X}_{1}=$ Kemampuan Produksi

$\mathrm{X}_{2}=$ Luas Lahan

$\mathrm{X}_{3}=$ Biaya Produksi

$\mathrm{b}_{1} \ldots \mathrm{b}_{5}=$ Koefisien regresi untuk masingmasing variabel $\mathrm{X}$ 
Tabel 7.

Hasil Uji Kelayakan Model Struktur 1

\begin{tabular}{llrrrrr}
\hline & Model & Sum of Squares & Df & Mean Square & F & Sig. \\
\hline 1 & Regression & 9,192 & 3 & 3,064 & 453,223 &, $000^{\text {b }}$ \\
& Residual &, 595 & 88 &, 007 & & \\
& Total & 9,786 & 91 & & & \\
\hline
\end{tabular}

Sumber:Data diolah, 2019

Tabel 8.

Hasil Uji Kelayakan Modal Struktur 2

\begin{tabular}{llrrrrr}
\hline & Model & Sum of Squares & Df & Mean Square & F & Sig. \\
\hline 1 & Regression & 16,753 & 4 & 4,188 & 252,646 &, $000^{\text {b }}$ \\
& Residual & 1,442 & 87 &, 017 & & \\
& Total & 18,195 & 91 & & & \\
\hline
\end{tabular}

Sumber:Data diolah, 2019

Tabel 9.

Hasil Analisis Jalur Regresi I

\begin{tabular}{|c|c|c|c|c|c|c|}
\hline \multicolumn{2}{|c|}{ Model } & \multicolumn{2}{|c|}{ Unstandardized Coefficients } & \multirow{2}{*}{$\begin{array}{c}\text { Standardized } \\
\text { Coefficients } \\
\text { Beta } \\
\end{array}$} & \multirow[t]{2}{*}{$\mathbf{t}$} & \multirow[t]{2}{*}{ Sig. } \\
\hline & & B & Std. Error & & & \\
\hline \multirow[t]{4}{*}{1} & (Constant) & 1,492 & ,774 & & 1,928 & 057 \\
\hline & Kemampuan Produksi &, 103 &, 022 & ,316 & 4,603 &, 000 \\
\hline & Luas Lahan & 340 & ,090 & ,353 & 3,793 &, 000 \\
\hline & Biaya Produksi & 341 &, 066 & ,336 & 5,137 & 000 \\
\hline
\end{tabular}

Sumber: Data diolah, 2019

dari variabel kemampuan produksi. Variabel kemampuan produksi (X1) terdiri atas 3 (tiga) indikator, yaitu penanaman, perawatan, dan pemanenan dengan 3 pernyataan. Dimana dari indikator untuk variabel kemampuan produksi tersebut menunjukkan nilai MSA masing-masing indikator variabel lebih besar dari 0,5 yang berarti masing-masing model layak digunakan dalam analisis. Indikator yang memiliki nilai MSA tertinggi adalah pemanenan $(\mathrm{X} \neg 1.3)$ yaitu sebesar 0,763 , disusul indikator perawatan (X1.2) sebesar 0,749 , dan penanaman (X1.1) sebesar 0,722. Hal ini menunjukkan bahwa pemanenan adalah indikator dominan yang mempengaruhi variabel kemampuan produksi.

Uji kelayakan model atau yang lebih popular disebut uji F (uji simultan) merupakan tahapan awal untuk mengidentifikasi model regresi yang diestimasi layak atau tidak. Layak berarti model yang diestimasi layak/ tepat digunakan untuk menjelaskan pengaruh variabel-variabel bebas terhadap variabel terikat. Nama uji ini disebut sebagai uji $\mathrm{F}$, karena mengikuti distribusi $\mathrm{F}$ yang kriteria pengujiannya seperti One Way Anova. Sig. Tabel ANOVA menunjukkan besarnya angka probabilitas atau signifikansi pada perhitungan ANOVA. Nilai yang tertera digunakan untuk uji kelayakan Model Analisis atau dimana sejumlah variabel $\mathrm{X}$ mempengaruhi variabel Y dengan ketentuan angka signifikansi yang baik untuk digunakan sebagai model regresi harus $<0,05$. Nilai ini bisa dilihat pada kolom signifikan. Jika signifikan $<0,05$, maka Model Analisis dianggap layak. Hasil uji kelayakan model pada struktur 1 disajikan pada Tabel 7.

Tabel 7 menunjukkan nilai signifikan sebesar 0,000 yang lebih kecil dari nilai $\alpha=0,05$ maka model yang digunakan pada penelitian ini adalah layak. Hasil ini memberikan makna bahwa kemampuan produksi, luas lahan, dan biaya produksi mampu memprediksi atau menjelaskan jumlah produksi, ini berarti model pada struktur 1 dapat digunakan untuk analisa lebih lanjut atau dengan kata lain 
Tabel 10.

Hasil Analisis Jalur Regresi 2

\begin{tabular}{|c|c|c|c|c|c|c|}
\hline \multicolumn{2}{|c|}{ Model } & \multicolumn{2}{|c|}{ Unstandardized Coefficients } & \multirow{2}{*}{$\begin{array}{c}\text { Standardized } \\
\text { Coefficients } \\
\text { Beta } \\
\end{array}$} & \multirow[t]{2}{*}{$\mathbf{t}$} & \multirow[t]{2}{*}{ Sig. } \\
\hline & & B & Std. Error & & & \\
\hline \multirow[t]{5}{*}{1} & (Constant) & 9,678 & 1,237 & & 7,823 & 000 \\
\hline & Kemampuan Produksi &, 063 &, 039 & 141 & 1,604 &, 112 \\
\hline & Luas Lahan & ,445 & 151 & ,339 & 2,939 & 004 \\
\hline & Biaya Produksi &,- 103 & ,119 &,- 074 &,- 866 & ,389 \\
\hline & Jumlah Produksi &, 772 & ,167 &, 566 & 4,625 & 000 \\
\hline
\end{tabular}

Sumber: Data diolah, 2019

model dapat digunakan untuk memproyeksi karena hasil goodness of fitnya baik dengan nilai $\mathrm{F}$ hitung sebesar 453,223 dengan nilai signifikansi 0,000 .

Sedangkan hasil uji kelayakan model struktur 2 pada penelitian ini disajikan pada Tabel 8 berikut.

Tabel 8 menunjukkan nilai signifikan sebesar 0,000 yang lebih kecil dari nilai $\alpha=0,05$ maka model yang digunakan pada penelitian ini adalah layak. Hasil ini memberikan makna bahwa kemampuan produksi, luas lahan, biaya produksi dan jumlah produksi mampu memprediksi atau menjelaskan pendapatan, ini berarti model pada struktur 2 dapat digunakan untuk analisa lebih lanjut atau dengan kata lain model dapat digunakan untuk memproyeksikan karena hasil goodness of fitnya baik dengan nilai $\mathrm{F}$ hitung sebesar 252,646 dengan nilai signifikansi sebesar 0,000 .

Pengujian persamaan satu dilakukan untuk melihat pengaruh kemampuan produksi, luas lahan, dan biaya produksi terhadap jumlah produksi petani pisang di Kecamatan Selemadeg Barat, Kabupaten Tabanan secara langsung, hasil uji regresi disajikann dalam Tabel 9 berikut.

Berdasarkan hasil Tabel 9 maka persamaan sub-struktural 1 adalah sebagai berikut:

$\mathrm{Y}_{1}=0,316 \mathrm{X}_{1}+0,353 \mathrm{X}_{2}+0,336 \mathrm{X}_{3}$

Berdasarkan hasil Tabel 9 maka persamaan sub-struktural 2 adaalah sebagai berikut :

$\mathrm{Y}_{2}=0,141 \mathrm{X}_{1}+0,339 \mathrm{X}_{2}-0,074 \mathrm{X}_{3}+0,566 \mathrm{Y}_{1}$

Untuk mengetahui nilai e $e_{1}$ yang menunjukkan jumlah variance variabel jumlah produksi yang tidak dijelaskan oleh kemampuan produksi, luas lahan, dan biaya prodduksi dapat dihitung dengan menggunakan rumus :

$\mathrm{e} 1=\sqrt{ } 1-\mathrm{R} 1^{2}$

$$
\begin{aligned}
& =\sqrt{ } 1-0,939 \\
& =0,246
\end{aligned}
$$

Sedangkan untuk mengetahui nilai $\mathrm{e}_{2}$ yang menunjukkan variance variabel pendapatan petani yang tidak dijelaskan oleh variabel kemampuan produksi, luas lahan, biaya produksi dan jumlah produksi maka dapat dihitung dengan menggunakan rumus :

$\mathrm{e} 2=\sqrt{ } 1-\mathrm{R} 2^{2}$

$$
\begin{aligned}
& =\sqrt{ } 1-0,921 \\
& =0,281
\end{aligned}
$$

Untuk memeriksa validitas model, terdapat indikator untuk melakukan pemeriksaan, yaitu koefisien determinasi total hasilnya sebagai berikut :

$$
\begin{aligned}
\mathrm{R}_{\mathrm{m}}^{2} & =1-\left(\mathrm{Pe}_{1}\right)^{2}\left(\mathrm{Pe}_{2}\right)^{2} \\
& =1-(0,246)^{2}(0,281)^{2} \\
& =0,995
\end{aligned}
$$

Keterangan:

$\mathrm{R}_{\mathrm{m}}^{2} \quad$ : Koefisien determinasi total

$\mathrm{e}_{1}, \mathrm{e}_{2}$ : Nilai kekeliruan taksiran standar Berdasarkan hasil perhitungan koefisien determinasi total, maka diperoleh bahwa keragaman data yang dapat dijelaskan oleh model adalah sebesar 0,995 atau dengan kata lain informasi yang terkandung dalam data sebesar 99,5 persen dapat dijelaskan oleh model, sedangkan sisanya 0,5 persen dijelaskan oleh variabel lain yang tidak terdapat dalam model.

Berdasarkan hasil analisis yang 
Tabel 10.

Hasil Pengaruh Langsung, Pengaruh Tidak Langsung dan Pengaruh Total Antar Variabel

\begin{tabular}{cccc}
\hline \multirow{2}{*}{ Hubungan Variabel } & \multicolumn{2}{c}{ Pengaruh } & \multirow{2}{*}{ Total } \\
\cline { 2 - 3 } & Langsung & Tidak Langsung & \\
\hline $\mathrm{X} 1 \rightarrow \mathrm{Y} 1$ & 0,316 & - & 0,316 \\
$\mathrm{X} 1 \rightarrow \mathrm{Y} 2$ & 0,141 & 0,178 & 0,319 \\
$\mathrm{X} 2 \rightarrow \mathrm{Y} 1$ & 0,353 & - & 0,353 \\
$\mathrm{X} 2 \rightarrow \mathrm{Y} 2$ & 0,339 & 0.199 & 0,538 \\
$\mathrm{X} 3 \rightarrow \mathrm{Y} 1$ & 0,336 & - & 0,336 \\
$\mathrm{X} 3 \rightarrow \mathrm{Y} 2$ & $-0,074$ & 0,190 & 0,116 \\
$\mathrm{Y} 1 \rightarrow \mathrm{Y} 2$ & 0,566 & - & 0,566 \\
\hline Sumber:Data diolah, 2019 & & &
\end{tabular}

Sumber:Data diolah, 2019

telah dilakukan diperoleh nilai standardized coefficients beta sebesar 0,316 dan nilai signifikansi sebesar $0,000<0,05$. Hal ini berarti $\mathrm{H}_{0}$ ditolak dan $\mathrm{H}_{1}$ diterima. Dengan demikian dapat disimpulkan bahwa kemampuan produksi berpengaruh positif dan signifikan terhadap jumlah produksi pisang di Kecamatan Selemadeg Barat, Kabupaten Tabanan.

Berdasarkan hasil analisis yang telah dilakukan diperoleh nilai standardized coefficients beta sebesar 0,353 dan nilai signifikansi $0,000<0,05$. Hal ini berarti $\mathrm{H} 0$ ditolak dan $\mathrm{H} 1$ diterima. Dengan demikian dapat disimpulkan bahwa luas lahan berpengaruh positif dan signifikan terhadap jumlah produksi pisang di Kecamatan Selemadeg Barat, Kabupaten Tabanan.

Berdasarkan hasil analisis yang telah dilakukan diperoleh nilai standardized coefficients beta sebesar 0,336 dan nilai signifikansi sebesar $0,000<0,05$. Hal ini berarti H0 ditolak dan H1 diterima. Dengan demikian dapat disimpullkan bahwa biaya produksi berpengaruh positif dan signifikan terhadap jumlah produksi pisang di Kecamatan Selemadeg Barat, Kabupaten Tabanan. Dapat dilihat bahwa semakin tinggi atau semakin banyak biaya produksi maka jumlah produksi semakin meningkat.

Berdasarkan hasil analisis yang telah dilakukan diperoleh nilai standardized coefficients beta sebesar 0,141 dan nilai signifikansi sebesar $0,112>0,05$. Hal ini berarti H0 diterima dan H1 ditolak. Dengan demikian kemampuan produksi tidak berpengaruh langsung terhadap pendapatan petani pisang di Kecamatan Selemadeg Barat, Kabupaten Tabanan. Hubungan positif dan tidak signifikan antara kemampuan produksi dengan pendapatan dikarenakan kemampuan produksi yang dimiliki oleh petani pisang tidak mampu meningkatkan pendapatan jika tidak mampu meningkatkan jumlah produksi pisang.

Berdasarkan hasil analisis yang telah dilakukan diperoleh nilai standardized coefficients beta sebesar 0,339 dan nilai signifikansi sebesar $0,004<0,05$. Hal ini berarti $\mathrm{H} 0$ ditolak dan $\mathrm{H} 1$ diterima. Dengan demikian dapat disimpulkan luas lahan berpengaruh positif dan signifikan terhadap pendapatan petani pisang di Kecamatan Selemadeg Barat, Kabupaten Tabanan.

Berdasarkan hasil analisis yang telah dilakukan diperoleh nilai standardized coefficients beta sebesar -0,074 dan nilai siginifikansi $0,389>0,05$. Hal ini berarti $\mathrm{H} 0$ diterima dan H1 ditolak. Dengan demikian biaya produksi tidak berpengaruh langsung terhadap pendapatan petani pisang di Kecamatan Selemadeg Barat, Kabupaten Tabanan. Hubungan negatif dan tidak signifikan antara biaya produksi dengan pendapatan dikarenakansemakin banyak biaya yang dikeluarkan dalam proses berporduksi maka akan mengurangi pendapatan yang didapatkan oleh petani.

Berdasarkan hasil analisis yang telah dilakukan diperoleh standardized coefficients 
beta sebesar 0,566 dan nilai signifikansi $0,000<0,05$. Hal ini berarti $\mathrm{H}_{0}$ ditolak dan $\mathrm{H}_{1}$ diterima. Dengan demikian dapat disimpulkan bahwa jumlah produksi berpengaruh positif dan signifikan terhadap pendapatan petani pisang di Kecamatan Selemadeg Barat, Kabupaten Tabanan.

Jika $\mathrm{z}$ hitung $\leq 1,96$ maka $\mathrm{H}_{0}$ diterima yang berarti jumlah produksi bukan variabel intervening. Jika $\mathrm{z}$ hitung $>1,96$ maka $\mathrm{H}_{0}$ ditolak yang berarti jumlah produksi merupakan variabel intervening.

$$
\begin{aligned}
\mathrm{S}_{\mathrm{b} 1 \mathrm{b7}} & =\sqrt{ } \beta 7^{2} \mathrm{~S}_{\beta 1}^{2}+\beta 1^{2} \mathrm{~S}_{\beta 7}^{2} \\
& =\sqrt{ }(0,772)^{2}(0,022)^{2}+(0,103)^{2}(0,167)^{2} \\
& =\sqrt{ }(0,595)(0,00048)+(0,010)(0,027) \\
& =\sqrt{ }(0,00028)+(0,00027) \\
& =\sqrt{ } 0,00055 \\
& =0,0234 \\
\mathrm{Z} & =\frac{\beta_{1} \beta_{7}}{\mathrm{~S} \beta_{1} \beta_{7}} \\
& =\frac{(0,103)(0,772)}{0,0234} \\
& =\frac{0,0795}{0,0234}=3,39
\end{aligned}
$$

Keterangan :

$\beta_{1}=$ Koefisien regresi pengaruh variabel $X_{1}$ terhadap $\mathrm{Y}_{1}$

$\beta_{7}=$ Koefisien regresi pengaruh variabel $Y_{1}$ terhadap $\mathrm{Y}_{2}$

$\mathrm{S} \beta_{1}=$ Standar error koefisien regresi variabel $\mathrm{X}_{1}$ terhadap $\mathrm{Y}_{1}$

$\mathrm{S} \beta_{7}=$ Standar error koefisien regresi variabel $\mathrm{Y}_{1}$ terhadap $\mathrm{Y}_{2}$

Berdasarkan hasil $\mathrm{z}$ hitung yaitu sebesar 3,39 > 1,96 maka $\mathrm{H}_{0}$ ditolak dan $\mathrm{H}_{1}$ diterima. Artinya kemampuan produksi berpengaruh secara tidak langsung terhadap pendapatan melalui jumlah produksi pisang di Kecamatan Selemadeg Barat, Kabupaten Tabanan.

Jika $\mathrm{z}$ hitung $\leq 1,96$ maka $\mathrm{H}_{0}$ diterima yang berarti pendapatan bukan variabel intervening. Jika $\mathrm{z}$ hitung $>1,96$ maka $\mathrm{H}_{0}$ ditolak yang berarti pendapatan merupakan variabel intervening.

$$
\begin{aligned}
\mathrm{S}_{\mathrm{b} 2 \mathrm{~b} 7} & =\sqrt{ } \beta 7^{2} \mathrm{~S}_{\beta 2}^{2}+\beta 2^{2} \mathrm{~S}^{2}{ }_{\beta 7} \\
& =\sqrt{ }(0,772)^{2}(0,090)^{2}+(0,340)^{2}(0,167)^{2} \\
& =\sqrt{ }(0,595)(0,0081)+(0,115)(0,027) \\
& =\sqrt{ }(0,0048)+(0,0031)
\end{aligned}
$$

$$
\begin{aligned}
& =\sqrt{ } 0,0079 \\
& =0,0888 \\
Z & =\frac{\beta 2 \beta 7}{\mathrm{~S} \beta 2 \beta 7} \\
& =\frac{(0,340)(0,772)}{0,0888} \\
& =\frac{0,262}{0,0888}=2,95
\end{aligned}
$$

Keterangan :

$\mathrm{B}_{2}=$ Koefisien regresi pengaruh variabel $\mathrm{X}_{2}$ terhadap $\mathrm{Y}_{1}$

$\mathrm{B}_{7}=$ Koefisien regresi pengaruh variabel $\mathrm{Y}_{1}$ terhadap $\mathrm{Y}_{2}$

$\mathrm{S} \beta_{2}=$ Standar error koefisien regresi variabel $\mathrm{X}_{2}$ terhadap $\mathrm{Y}_{1}$

$\mathrm{S} \beta_{7}=$ Standar error koefisien regresi variabel $\mathrm{Y}_{1}$ terhadap $\mathrm{Y}_{2}$

Berdasarkan hasil $\mathrm{z}$ hitung yaitu sebesar 2,95 > 1,96 maka $\mathrm{H}_{0}$ ditolak dan $\mathrm{H}_{1}$ diterima. Artinya luas lahan berpengaruh secara tidak langsung terhadap pendapatan melalui jumlah produksi pisang di Kecamatan Selemadeg Barat, Kabupaten Tabanan.

Jika $\mathrm{z}$ hitung $\leq 1,96$, maka $\mathrm{H}_{0}$ diterima yang berarti Jumlah Produksi bukan variabel intervening. Jika $\mathrm{z}$ hitung $>1,96$, maka $\mathrm{H}_{0}$ ditolak yang berarti Jumlah Produksi merupakan variabel intervening.

$$
\begin{aligned}
\mathrm{S}_{\mathrm{b} 3 \mathrm{~b} 7} & =\sqrt{\beta} 7^{2} \mathrm{~S}_{\beta 3}^{2}+\beta 3^{2} \mathrm{~S}_{\beta 7}^{2}{ }^{\wedge} \\
& =\sqrt{ }(0,772)^{2}(0,066)^{2}+(0,341)^{2}(0,167)^{2} \\
& =\sqrt{ }(0,595)(0,0043)+(0,116)(0,027) \\
& =\sqrt{ }((0,0025)+(0,0031)) \\
& =\sqrt{ } 0,0056 \\
& =0,074 \\
Z \quad & =\frac{\beta 3 \beta 7}{\mathrm{~S} \beta 3 \beta 7} \\
& =\frac{(0,341)(0,772)}{0,074} \\
& =\frac{0,263}{0,074}=3,55
\end{aligned}
$$

Keterangan :

$\beta_{3}=$ Koefisien regresi pengaruh variabel $\mathrm{X}_{3}$ terhadap $\mathrm{Y}_{1}$

$\beta_{7}=$ Koefisien regresi pengaruh variabel $Y_{1}$ terhadap $\mathrm{Y}_{2}$

$\mathrm{S} \beta_{3}=$ Standar error koefisien regresi variabel $\mathrm{X}_{3}$ terhadap $\mathrm{Y}_{1}$

$\mathrm{S} \beta_{7}=$ Standar error koefisien regresi variabel $\mathrm{Y}_{1}$ terhadap $\mathrm{Y}_{2}$ 
Berdasarkan hasil $\mathrm{z}$ hitung yaitu sebesar 3,55 > 1,96 maka $\mathrm{H}_{0}$ ditolak dan $\mathrm{H}_{1}$ diterima. Artinya biaya produksi berpengaruh secara tidak langsung terhadap pendapatan melalui jumlah produksi pisang di Kecamatan Selemadeg Barat, Kabupaten Tabanan.

Berdasarkan hasil penelitian yang telah dilakukan, terdapat implikasi yang dapat dihasilkan dengan adanya penelitian ini. Hasil dari penelitian ini didapatkan bahwa kemampuan produksi berpengaruh positif dan signifikan terhadap jumlah produksi yang artinya semakin tinggi kemampuan produksi yang dimiliki oleh petani berupa pemahaman dalam bertani maka akan meningkatkan jumlah produksi. Selain itu dari hasil penelitian didapatkan bahwa luas lahan berpengaruh positif dan signifikan terhadap jumlah produksi yang artinya semakin besar luas lahan yang digunakan akan meningkatkan jumlah produksi tersebut. Serta pada penelitian ini juga didapatkan bahwa biaya produksi berpengaruh positif dan signifikan terhadap jumlah produksi yang artinya semakin banyak biaya produksi yang dikeluarkan maka akan meningkatkan jumlah produksi.

Hasil penelitian ini juga menemukan bahwa tidak terdapat pengaruh kemampuan produksi dan biaya produksi terhadap pendapatan, sedangkan luas lahan dan jumlah produksi berpengaruh positif dan signifikan terhadap pendapatan petani. Hal tersebut menunjukkan bahwa kemampuan produksi dan biaya produksi yang diterima oleh petani pisang tidak berpengaruh terhadap pendapatan petani.

Jumlah produksi memegang peranan penting dalam meningkatkan pendapatan petani pisang di Kecamatan Selemadeg Barat, Kabupaten Tabanan, maka orientasi pemikiran dan upaya dapat dilakukan dengan meningkatkan kemampuan produksi petani. Jika kemampuan produksi yang dimiliki baik, luas lahan yang dimiliki dimanfaatkan secara maksimal dan mampu menekan jumlah biaya akan mampu meningkatkan pendapatan petani dan dipercepat dengan jumlah produksi yang tinggi. Disamping itu juga penggunaan biaya produksi berperan penting untuk meningkatkan produksi pisang, dilhat bahwa semakin tinggi penggunaan biaya atau semakin banyak biaya produksi maka jumlah produksi semakin meningkat dan akan mampu meningkatkan pendapatan petani pisang.

\section{SIMPULAN}

Kemampuan produksi, luas lahan, dan biaya produksi berpengaruh positif dan signifikan terhadap jumlah produksi pisang di Kecamatan Selemadeg Barat, Kabupaten Tabanan.Kemampuan produksi mempunyai pengaruh positif dan tidak signifikan terhadap pendapatan petani pisang di Kecamatan Selemadeg Barat, Kabupaten Tabanan.Biaya produksi mempunyai pengaruh negatif dan tidak signifikan terhadap pendapatan petani pisang di Kecamatan Selemadeg Barat, Kabupaten Tabanan.Kemampuan produksi, luas lahan, dan biaya produksi memiliki pengaruh tidak langsung terhadap pendapatan petani pisang di Kecamatan Selemadeg Barat, Kabupaten Tabanan, atau dengan kata lain jumlah produksi merupakan variabel yang mengintervening kemampuan produksi, luas lahan dan biaya produksi terhadap pendapatan petani pisang di Kecamatan Selemadeg Barat, Kabupaten Tabanan.

Pemerintah daerah khususnya UPTD Kehutanan dan Perkebunan Kecamatan Selemadeg Barat, Kabupaten Tabanan dapat memberikan serta mampu menyediakan sarana prasarana bagi petani pisang di daerah tersebut juga memberikan penyuluhan atau pelatihan dan memberikan subsidi pupuk dengan jumlah yang lebih banyak sesuai dengan luas lahan yang dimiliki oleh petani pisang tersebut, dengan demikian dapat membantu meringankan biaya produksi yang dikeluarkan petani sehingga mampu meningkatkan produksi pisang dan pendapatan petani.

Peneliti menyarankan kepada petani pisang agar dapat memanfaatkan lahan perkebunan yang dimiliki sehingga mendapatkan hasil yang maksimal. Misalnya dengan menjaga kesuburan lahan perkebunan, melakukan perawatan yang optimal dan dalam prosses pemanenan agar dipilah terlebih dahulu yang dapat maksimalkan jumlah produksi. 
Petani pisang juga harus fokus pada pertanian pisang dalam hal ini akan membawakan pertanian pisang ke aspek pasar yang lebih besar dan mampu meningkatkan pendapatan petani pisang di Kecamatan Selemadeg Barat, Kabupaten Tabanan.

\section{REFERENSI}

Abedullah, Shahzad Kouser, and Khalid Mushtaq. 2007. Analysis of Technical Efficiency of Rice Production in Punjab (Pakistan), Implications For Future Investment Strategies. Pakistan Economic and Social Review, 45(2), pp:231-244.

Adi Wiguna, Putu, 2018. Peran Koperasi Unit Desa Dalam Meningkatkan Kesejahtraan Petani Di Indonesia (Analisis Data Mikro). E-Jurnal Ekonomi Pembangunan Unud, 7(1): Hal: 30-57

Adojutelegan, O. T., Adereti F.O., Makanju T. S., and Olorunfemi O. D. 2015. Analisys of Factors Affecting Watermelon Production in Ekiti State, Nigeria.Science, Technology and Arts Research Journal, 4(2), pp: 324-329.

Adriyansyah, Danny. 2017. Analisis Skala Ekonomis Dan Efisiensi Penggunaan Faktor-faktor Produksi Ipada Iusaha Iperkebunan Ikopi Arabika Di Desa Satra Kecamatani Kintamani Ikabupaten Bangli. E-Jurnal Ekonomi PembangunanUnud,6(2):Hal:178-194

Aldillah, Rizma. 2015. Proyeksi Produksi dan Konsumsi Kedelai Indonesia. Jurnal Ekonomi Kuantitatif Terapan, 8(1): h: 9-23

Alitawan. Anak Agung Irfan 2017. FaktorFaktor Yang Mempengaruhi Pendapatan Petani Jeruk Pada Desa Gunung Bau Kecamatan Kintamani Kabupaten Bangli.
Ambarita, Jerry Paska. 2015. Pengaruh Luas Lahan, Penggunaan Pestisida, Tenaga Kerja, Pupuk Terhadap Produksi Kopi Di Kecamatan Pekutatan Kabupaten Jembrana. E-Jurnal Ekonomi Pembangunan Universitas Udayana, 4 (7):Hal: 776-793.

Antara, Made 2013. Permintaan Buah Pisang Ambon Oleh Rumah Tangga di Kecamatan Denpasar Barat, Kota Denpasar Provinsi Bali Jurnal Ekonomi Kuantitatif Terapan, 6(1), hal.16-29.

Ardika, I Wayan 2017. Analisis Tingkat Kesejahteraan Petani Di Desa Bangli Kecamatan Baturiti Kabupaten Tabanan Jurnal Piramida 8 (2): Hal: $87-96$.

Budiartha, Agus I Kadek.2013. Analisis Skala Ekonomis Industri Pengrajin Batu Bata di Desa Tulikup Kecamatan Gianyar Kabupaten Gianyar. Jurnal Ekonomi Kuantitatif Terapan, 6(1), hal.55-61.

Breau, Sebastien, dan Richard Saillant. 2016. Regional Income Disparities in Canada:Exploring the Geographical Dimensions of an Old Debate. Journal Regional Studies, Regional Science, 3, pp.463-481.

Godby, Robert, et al., 2015. The Impact of the Coal Economy on Wyoming. The Journal of Economic and Fublic Policy. 2(2): pp: 234-254

Gouse, Marnus, Jenifer Piesse, and Colin Thirtle. 2006. Output and Labour Effects of GM Maize and Minimum Tillage in a Communal Area of KwaZulu-Natal. Journal of Development Perspectives, 2(2), pp:192-207

Jelocnik, Marko, Subic, Jonel, Nastic, Lana. 
2011. Analysis Of Agriculture And Rural Development In The Upper Danube Region-Swot Analysis. Journal International Agricultural Economics. ISSN: 22477187.

Jeon, Shinyoung. 2013. Agriculture Transformation and the Escape from the Middle Small Farmers in Indonesia in Time of Green Restucturing. Bulletin of Indonesian Economic Studies, 49:3, 383- 384

Limi, Muhammad Anwar. 2013. Analisis Jalur Pengaruh Faktor Produksi terhadap Produksi dan Pendapatan Usahatani Kacang tanah di Kecamatan Lembo Kabupaten Konawe Utara. Jurnal AGRIPLUS, 23(20, PP: 124-134

Lincoln, Noa Kekuewa \& Nicole Ardoin. 2016. Farmer Typology in South Kona, Hawai 'i: Who's Farming, How, and Why. International Journal of Multidisciplinary Research. $19: 3,563-585$

Mannan, Sobia \& Shahrina Md Nordin. 2014. The Influence Of Innovarion Attributes On New Technologies Adoption By Paddy Farmers. International Review Of Management And Business Research. 3(3). Pp 1379-1384.

Mariyah, Mariyah 2018. Penentuan Umur Optimal Peremajaan Kelapa Sawit di Kabupaten Paser Kalimantan Timur, Jurnal Ekonomi Kuantitatif Terapan, 11(1) : Hal: 103-115

Mubyarto. 1989. Pengantar Ekonomi Pertanian. Jakarta : Edisi Ketiga, LP3S

Mushi, Ally S, Deus D. Ngaruko, 2015. Determinants of financial Sustainability of Small Holder Sugarcane Farming systems in Tanzania. African journal of economic review III (2): 57-73

Nian Elly Ariessi. 2017. Pengaruh Modal, Tenaga Kerja Dan Modal Sosial Terhadap Produktivitas Petani Di Kecamatan Sukawati Kabupaten Gianyar Jurnal Piramida 8 (2): Hal: 97 - 107

Oluyole, K.A. and Sanusi, R.A. 2009. Socio-Economic Variables and Cocoa Production in Cross River State, Nigeria. Journal of Human Ecology, 25(1), pp:5-8

Prasetyo Didik dan kartika I Nengah, 2017, Analisis Faktor-Faktor yang mempengaruhi Produksi Ayam Broiler Di Kecamatan Marga, Kabupaten Tabanan, Jurnal Piramida Vol. 13 No. 2

Salazar, Marcia. 2006. An Economic Analysis of Smallholder Coffee Production in Guatemala, Honduras, Nicaragua and Vietnam. A Thesis of Purdue University, West Lafayatte Indiana.

Saputra, Ardhiyan. 2015. Faktor-Faktor yang Mempengaruhi Produksi Kakao di Kabupaten Muaro Jambi. Jurnal Penelitian Universitas Jambi Seri Sains, 17(2), hh: 1-8.

Shan, Kangkang and Anran Wang, 2015, Study on Separation of Factors of Production From Grain and Food Safety during the Evolution of Chinese Agricultural Structure, Journal of Asian Agricultural Research, 7(5), pp: 1-4

Sukartini, Achmad Solihin. 2013. Respon Petani Terhadap Perkembangan Teknologi dan Perubahan Iklim: Studi Kasus SUBAK di Desa Gadungan, Tabanan, Bali. Jurnal Ekonomi Kuantitatif Terapan, 
6 (2), hal: $128-139$.

Suryahadi, Asep, Gracia Hadiwidjaja and Sudarno Sumarto. 2012. Economic Growth and Poverty Reduction in Indonesia Before and After The Asian Financial Crisis. Bulletin of Indonesian Economic Studies, Vol. 48, No. 2, 2012: 209227.

Suryaniti. 2018. Analisis Faktor-Faktor yang Berpengaruh Terhadap Pendapatan Petani Jeruk di Kintamani, Kabupaten Bangli.
Winters Paul, Alain De Janvry, Elisabeth Sadoulet And Kostas Stamoulis 1998. The Role of Agriculture in Economic Development: Visible and Invisible Surplus Transfers. Vol.34, No.5. pp.71-97.

Yusuf, Arif Anshory and Andy Sumner. 2015. Growt, Poverty and Inequality Under Jokowi. Bulletin of Indonesian Economic Studies, 51 (3), pp.323-348. 